\title{
Photosynthetic Activity of Superior Varieties and Local Cassava (Manihot esculenta Crantz) Indonesia
}

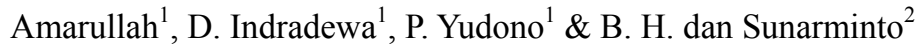 \\ ${ }^{1}$ Department of Agronomy, Faculty of Agriculture, Universitas Gajah Mada, Jl. Flora, Bulaksumur, Yogyakarta, \\ Indonesia \\ 2 Department of Soil Science, Faculty of Agriculture, Universitas Gajah Mada, Jl. Flora, Bulaksumur, \\ Yogyakarta, Indonesia \\ Correspondence: Amarullah, Department of Agronomy, Faculty of Agriculture, Universitas Gajah Mada, Jl. \\ Flora, Bulaksumur, Yogyakarta, Indonesia. E-mail: amarullah70@g.mail.com
}

Received: May 23, 2016

doi:10.5539/jas.v8n8p194

\author{
Accepted: July 3, $2016 \quad$ Online Published: July 15, 2016 \\ URL: http://dx.doi.org/10.5539/jas.v8n8p194
}

\begin{abstract}
Productivity relates to the ability of photosynthesis. Therefore, the process of photosynthesis is important to promote growth, development and yield. There are many varieties of superior and local cassava (Manihot esculenta Crantz) in Indonesia either unknown of their photosynthesis character. The study aims to investigate the characteristics of photosynthesis and influences of physiological parameters associated the activity of photosynthesis in cassava plants. A study was conducted on Inceptisol soils at UGM research at altitude $113 \mathrm{~m}$ above mean sea level between January and November 2014. The treatment of single factor is cassava varieties consist of Adira-4, Malang-6, UJ-5, Singgah and Ketan arranged in a randomized block design with three replications. Cuttings size $\pm 20 \mathrm{~cm}$ are planted upright with a distance of $1 \mathrm{~m} \times 1 \mathrm{~m}$ (population of 10,000 plants $\mathrm{ha}^{-1}$ ). After six months, observation has been done of characters and physiological activities at 10 samples per plots and per varieties. The results showed that there are differences in the density of stomata, stomata aperture width, water content, chlorophyll content and photosynthesis rate between varieties of cassava. Singgah varieties have the Ksd highest with medium Lbs and varieties local of Ketan lowest Ksd. The group of superior varieties of cassava have Kkt medium, but varieties of Malang-6 have Kkt slightly higher and the highest rate of photosynthesis. Singgah varieties have lowest leaves Kkt and medium rate of photosynthesis. Local varieties of Ketan have the highest Kkt and lowest rate of photosynthesis. Group cassava superior varieties had higher photosynthesis rate than the local varieties, local varieties Singgah has a moderate rate and higher than Ketan. Stomata density and the concentration of $\mathrm{CO}_{2}$ correlated positively and significantly affect the rate of photosynthesis while transpiration increase conductivity stomatal but negatively correlated to the rate of photosynthesis.
\end{abstract}

Keywords: photosynthetic, superior, local, varieties, cassava

\section{Introduction}

Prospects for the development of cassava commodities continue to rise in line with the increasing diversification of the need for raw materials are sourced from cassava. In some countries, cassava becomes the staple food and partly used for processed into alternative food. The economic value of cassava can be increased if used as biofuels (biofuels), especially with the depletion of world oil reserves that make cassava demand is increasing in some other countries. The growing need and high demand for cassava should be offset by the ability of cassava production and the need to support varieties with high productivity. Crop productivity associated with the ability of photosynthesis. Therefore, the process of photosynthesis is important to promote growth, development and yield. Generally photosynthesis is affected by leaf characteristics (age, and leaf morphology), the magnitude of the needs of the results of assimilation by the sink and environmental factors (Sinclair \& Torrie, 1989). The rate of photosynthesis is directly related crop factor, such as the characteristic phenotype (Turyagyenda et al., 2013), genetic crop, age of leaves and chlorophyll as well as prisoners stomata of the leaves and environmental factors that morphology and response leaves to light (Okgbenin et al., 2010), the availability of water and gas exchange (Naves-Barbiero et al., 2000), and $\mathrm{CO}_{2}$ (Oliveira \& Miglioranza, 2014). Cassava is a $\mathrm{C}_{3}$ plant based on a number of physiological and biochemical photosynthetic characteristics (Edwards et al., 1990). Genetically, the plant has 
a C4 photosynthetic rate lower than $\mathrm{C} 3$. Cassava plant photosynthesis including the $\mathrm{C} 3$ pathway of photosynthesis rate variation 15-29 mol CO $\mathrm{m} \mathrm{m}^{-2} \mathrm{~s}^{-1}$, in normal sunlight and 5.5-7.32 mol CO2 m $\mathrm{m}^{-2} \mathrm{~s}^{-1}$ on solar light shaded (Aspiazu et al., 2006). The evaluation results CIAT taahun 1992/1993 to five varieties of cassava with high photosynthetic capacity (SM 1961-1, SM 526-12, SM 1054-4, SM 1053-9 and MP 501) are grown at an altitude of $1.800 \mathrm{~m}$ in Cajibio, Brazil respectively - masing obtained 17.3, 16.7, 16.6, 15.7 and $16.4 \mathrm{~mol} \mathrm{CO}_{2}$ $\mathrm{m}^{-2} \mathrm{~s}^{-1}$. Similarly, the results of the evaluation of CIAT 1994 against eight varieties of Argentina (HQ), one of Brazil (M Br), one of Colombia (HMC 1) and one from Bolivia (M Bol 1) obtained average photosynthesis varieties Argentina significantly higher $26 \mathrm{~mol} \mathrm{CO}_{2} \mathrm{~m}^{-2} \mathrm{~s}^{-1}$ compared varieties from Brazil $22 \mathrm{~mol} \mathrm{CO}_{2} \mathrm{~m}^{-2} \mathrm{~s}^{-1}$. The research results, Aien et al. in 2008-2009 to two solar kufri verieties potatoes and kufri Chipsona-3 obtained by variation of photosynthesis of 10:21 and 11:50 $\mathrm{mol} \mathrm{CO}_{2} \mathrm{~m}^{-2} \mathrm{~s}^{-1}$. Chlorophyll is an important photoreceptor pigment that absorbs light energy and transfers energy to the photosynthetic system (Demmig et al., 1996). Chlorophyll content is used for the determination of stay green or leaf senescence (Bahar, 2015). The aging of leaves increases the amount of chlorophyll. Increasing the amount of chlorophyll increases the ability of plants to approaching the sunlight so as to accelerate the rate of photosynthesis. Stomata are the first window for gas exchange in leaves and they are the key structures responsible for the control of $\mathrm{CO}_{2}$ uptake and water loss via transpiration (Adedeji \& Jewoola, 2008). The stomata occupy a central position in the pathways (1968) for both the loss of water from plants and the exchange of $\mathrm{CO}_{2}$. It is commonly assumed that they therefore provide the main short-term control of both transpiration and photosynthesis (Jones, 1998). Stomata respond to environmental stimuli to balance hydraulic and photosynthetic needs (Creese et al., 2014). It is clear that there is a strong relationship between environmental conditions and stomatal size and density, and the responses are variable between species (Christman et al., 2008; Franks \& Farkuhar, 2007). In the absence of stomata, the supply of carbon dioxide for photosynthesis would be inadequate for survival of most plants, but at the same time the unavoidable loss of water vapor through them creates the danger of dehydration. Thus, the ability of stomata to adjust their aperture is extremely important to the success of plants (Cowan, 1982; Savvides et al., 2012). Conductivity is a barrier that causes the stomata can not absorb $\mathrm{CO}_{2}$ and air maximally that consequently affect the ability of plants to perform photosynthesis. Basically, chlorophyll absorbs light optimally at light with red and blue colors. When light is received either red or blue by chlorophyll, the photosynthesis will be faster. Long exposure tridak affects the rate of photosynthesis every minute or hour but fotosintat affects the amount that will be produced in a single day. Carbon dioxide is one of the main elements that are used as ingredients of photosynthesis. By the time the plant receives light thus increasing $\mathrm{CO}_{2}$ and will increase the rate of photosynthesis. The availability of water is the main ingredient of photosynthesis. Water effects on plant turgor. The more the water content, the better the plant turgor was followed by an increase in stomatal opening. Stomatal opening increases $\mathrm{CO}_{2}$ diffusion and increase the speed of photosynthesis. In the cassava plant, light is important in the biosynthesis of chlorophyll and chloroplast maturation, stomatal opening, the synthesis of the enzyme and the entire process of photosynthesis and yield (Samuoliene et al., 2010). High leaf retention illustrates the level of leaf greenness (Nuwamanya et al., 2014a), if it is associated with high chlorophyll content can increase the yield and efficiency of transpiration (Borell et al., 2000). Increase production of chlorophyll increases the efficiency of photosynthesis (Nuwamanya et al., 2015). Cassava plants require high temperature and high solar radiation for optimal development and to the expression of leaf photosynthetic potential (El-Sharkawy et al., 2015). Each plant has in addition agronomic and physiological characteristics of different Morphological causing differences in photosynthetic activity that may affect the results of cassava. There are many varieties of cassava in Indonesia either superior or local unknown photosynthetic character. This underlies the need for research on photosynthesis characters of different varieties of cassava as one of the indicators of cassava plant. The purpose of this study was to determine the photosynthetic activity and variable contribution associated with the activity of the cassava plant photosynthesis.

\section{Materials and Methods}

\subsection{Site}

The field study was conducted on the ground in the garden Inceptisol soils at UGM research at altitude $113 \mathrm{~m}$ above mean sea level between January and November 2014

\subsection{Experiment Design}

The treatment of single factor cassava varieties consist of Adira-4, Malang-6, UJ-5, Singgah and Ketan arranged in a randomized block design with three replications. Size $\pm 20 \mathrm{~cm}$ cuttings are planted upright with a distance of $1 \mathrm{~m} \times 1 \mathrm{~m}$ population of 10.000 plants ha $^{-1}$. Six months after planting observation of character and physiological activity in 10 samples perplot pervarietas. 


\subsection{Implementation of Field Research}

Planting activity conducted in stages; tillage and planting material, planting, maintenance and harvesting. Size $\pm 20 \mathrm{~cm}$ cuttings material is sliced horizontally and planted upright in research plots measuring $5 \times 7 \mathrm{~m}$ with a spacing of $1 \times 1 \mathrm{~m}$ (population of 525 plants or the equivalent of 10.000 plants $^{-1} \mathrm{a}^{-1}$ ). Cassava plant maintenance is done in a way; weeding 2 times before fertilization and in conjunction with hoarding to soil by loosening the soil, fertilizing with urea, SP36 and $\mathrm{KCl}$ at a dose of 200,100 , and $100 \mathrm{~kg} \mathrm{ha}^{-1}$, given half doses at age 1 month, then the rest is given again at age 3 month. While organic fertilizers such as manure is given at the age of 1 month with a rate 20 ton $\mathrm{ha}^{-1}$.

\subsection{Yield and Observation}

Observations of physiological parameters include; observations of greenness leaves by taking several samples of leaves every varieties of cassava when plants are aged 6 months after planting measured by Chlorophyll meter SPAD 502 Minolta (Gardner et al., 1991), chlorophyll content observed by taking some leaf samples measured by Spectrophotometer Spectronic 21D (Ross, 1974), the density and width of stomata observed on the back part of leaves using microscope, sunlight observed at the top and bottom of the cassava plant when the sun shines full and measured using a Lux meter. Results photosynthesis and other physiological activities observed with photosynthetic analyzer-type $\mathrm{Li}$ COR 6400.

\subsection{Statistical Analysis}

The data were analyzed by analysis of variance, when there significant followed by Dun'can Multiple Range Test (DMRT) at level 5\% error (K. A. Gomez \& A. A. Gomez, 1984). Relationships between variables observations sought by accounting coefisien correlation (Simonte at al., 1998). Data were processed using SAS program Portable 9.1.3 for the F test (SAS, 2002) and SPSS 19 for correlation.

\section{Results}

Statistical analysis showed no significant differences some physiological characteristics and physiological activity between the varieties of cassava, as shown in Table 1 .

Table 1. Physiological activity several varieties of cassava plant

\begin{tabular}{llllll}
\hline \multirow{2}{*}{ Variable observation } & \multicolumn{5}{c}{ Varity } \\
\cline { 2 - 6 } & Adira-4 & Malang-6 & $\mathrm{UJ}-5$ & Singgah & Ketan \\
\hline The density of stomata $\left(\mathrm{mm}^{2}\right)$ & $93.78 \mathrm{ab}$ & $73.89 \mathrm{bc}$ & $66.22 \mathrm{c}$ & $110.78 \mathrm{a}$ & $68.56 \mathrm{c}$ \\
Stomatal aperture width $(\mu \mathrm{m})$ & $8.46 \mathrm{c}$ & $12.67 \mathrm{a}$ & $8.38 \mathrm{c}$ & $10.36 \mathrm{~b}$ & $6.07 \mathrm{~d}$ \\
Conductivity stomata $\left(\mathrm{mol} \mathrm{H}_{2} \mathrm{O} \mathrm{m}^{-2} \mathrm{~s}^{-1}\right)$ & $0.17 \mathrm{a}$ & $0.16 \mathrm{a}$ & $0.17 \mathrm{a}$ & $0.21 \mathrm{a}$ & $0.29 \mathrm{a}$ \\
The content of $\mathrm{H}_{2} \mathrm{O}\left(\mathrm{mmol} / \mathrm{mol}^{-1}\right)$ & $35.41 \mathrm{~b}$ & $36.49 \mathrm{ab}$ & $37.99 \mathrm{a}$ & $36.45 \mathrm{ab}$ & $36.54 \mathrm{ab}$ \\
The $\mathrm{CO}_{2}$ content of the celll $\left(\mu \mathrm{mol} / \mathrm{mol}^{-1}\right)$ & $305.24 \mathrm{a}$ & $304.37 \mathrm{a}$ & $310.87 \mathrm{a}$ & $306.19 \mathrm{a}$ & $315.40 \mathrm{a}$ \\
Total chlorophyl $\left(\mathrm{mg} \mathrm{g} \mathrm{g}^{-1}\right)$ & $1.01 \mathrm{c}$ & $1.08 \mathrm{~b}$ & $1.04 \mathrm{c}$ & $0.95 \mathrm{~d}$ & $1.14 \mathrm{a}$ \\
Activities ofs transpiration $\left(\mathrm{mmol} \mathrm{H}_{2} \mathrm{O} \mathrm{m}^{-2} \mathrm{~s}^{-1}\right)$ & $3.36 \mathrm{a}$ & $3.18 \mathrm{a}$ & $2.91 \mathrm{a}$ & $4.19 \mathrm{a}$ & $3.97 \mathrm{a}$ \\
The rate of photosynthesis $\left(\mu \mathrm{mol} \mathrm{CO} \mathrm{m}^{-2} \mathrm{~s}^{-1}\right)$ & $42.33 \mathrm{ab}$ & $144.33 \mathrm{a}$ & $141.33 \mathrm{ab}$ & $140.00 \mathrm{ab}$ & $135.00 \mathrm{~b}$ \\
\hline
\end{tabular}

Note. The average values followed by the same letters in the same column are not significantly different at $5 \%$ DMRT.

There is no difference in the conductivity of stomata, transpiration rate and the $\mathrm{CO}_{2}$ content of cells, but there are differences in the density and width of stomata, $\mathrm{H}_{2} \mathrm{O}$ content, total chlorophyll content and photosynthesis rate among cassava varieties studied (Table 1). Singgah local varieties have the highest density of stomata although not significantly different from the density of stomata varieties Adira-4. Stomata widest occur in Malang superior verietas- 6 and significantly different from other varieties, while the narrowest on local verietas Ketan. Ketan local varieties have the highest total chlorophyll content and significantly different from the varieties Adira-4, Malang-6 and UJ-5, but local varieties Singgah it has the lowest chlorophyll content between varieties studied. Local varieties of cassava photosynthesis rate equal Singgah varieties Adira-4 and UJ-5, although slightly slower than varieties Malang 6 but faster than the local varieties Ketan.

The $\mathrm{H}_{2} \mathrm{O}$ content of cassava varieties UJ-5 higher and significantly different from the varieties of Adira-4, but did not differ with varieties Malang-6, Singgah and Ketan. The concentration of $\mathrm{CO}_{2}$, stomatal conductivity and 
transpiration of leaves, although not significantly different between the varieties, but there is a relationship between the three. Cassava varieties Ketan memeiliki higher total chlorophyll content and is different from the four other varieties but has a density of stomata narrowest tenuous invitation, otherwise cassava varieties Singgah generate total chlorophyll content of at least but it has the most stomata and meetings. Malang- 6 cassava variety produces enough chlorophyll content and has a number and density of stomata were in fact have the widest stomata. Correlation of stomatal density, width of stomata, stomata conductivity, leaf transpiration, water content, content of $\mathrm{CO}_{2}$, concentration of chlorophyll in photosynthesis, the correlation matrix presented in Table 2 .

Table 2. Matrix correlation of physiological characteristics of cassava plants

\begin{tabular}{llllllll}
\hline & $\mathrm{Dsl}$ & $\mathrm{Ws}$ & $\mathrm{Cs}$ & $\mathrm{Tl}$ & $\mathrm{H}_{2} \mathrm{O}$ & $\mathrm{CO}_{2}$ & $\mathrm{Lc}$ \\
\hline $\mathrm{Dsl}$ & - & & & & & & \\
$\mathrm{Ws}$ & 0.27 & - & & & & & \\
$\mathrm{Cs}$ & 0.48 & -0.38 & - & & & & \\
$\mathrm{Tl}$ & 0.58 & -0.22 & $0.93^{* *}$ & - & & & \\
$\mathrm{H}_{2} \mathrm{O}$ & -0.55 & -0.07 & -0.07 & -0.38 & - & & \\
$\mathrm{CO}_{2}$ & -0.55 & 0.28 & $-0.95^{* *}$ & $-0.99^{* *}$ & 0.33 & - & \\
$\mathrm{Lc}$ & $-0.85^{* *}$ & -0.36 & -0.20 & -0.16 & 0.15 & 0.15 & - \\
$\mathrm{rP}$ & 0.14 & $0.81^{* *}$ & $-0.75^{*}$ & -0.65 & -0.08 & $0.69^{*}$ & -0.41 \\
\hline
\end{tabular}

Note. $\mathrm{N}=15$ samples; $*=$ a real contrast to the $\mathrm{t}$ test $(\mathrm{P}<0.05) ; \mathrm{Dsl}=$ density of stomata of the leaves $\left(\mathrm{mm}^{2}\right)$; $\mathrm{Ws}=$ width of stomata $(\mathrm{m}) ; \mathrm{Cs}=$ conductivity of stomata $\left(\mathrm{mol} \mathrm{m}^{-2} \mathrm{~s}^{-1}\right) ; \mathrm{Td}=$ activity transpiration leaf (mmol $\left.\mathrm{m}^{-2} \mathrm{~s}^{-1}\right) ; \mathrm{H}_{2} \mathrm{O}=$ water content $\left(\mathrm{mmol} / \mathrm{mol}^{-1}\right) ; \mathrm{CO}_{2}=\mathrm{CO}_{2}$ content $\left(\mathrm{mmol} / \mathrm{mol}^{-1}\right) ; \mathrm{Kd}=$ leaf chlorophyll $\left(\mathrm{mg} \mathrm{g}^{-1}\right) ; \mathrm{Fd}$ $=$ rate of photosynthesis $\left(\mathrm{mol} \mathrm{m}^{-2} \mathrm{~s}^{-1}\right)$.

Table 2 shows that the density of stomata of the leaves was positively correlated with transpiration. Most of transpiration occurs through stomata, although it can also be through the cuticle. Stomata more opened will increase its conductivity, so transpiration faster. When stomata are open then there will be a liaison between the cavities between cells and atmosfer.

The rate of photosynthesis resulted in $\mathrm{CO}_{2}$ levels in the cell decreased. Cassava varieties Malang- 6 produces the highest photosynthetic rate and significantly different from the four other varieties, especially varieties of Ketan. The results showed that the photosynthetic rate was highest in varieties Malang-6 were significantly higher than the rate of photosynthesis Ketan local varieties, but no different than other varieties. Singgah varieties have medium rate of photosynthesis, not significantly different from the rate of photosynthesis other varieties.

This occurs because the varieties Singgah and Adira-4 that have a high density of stomata, stomata tend to have a medium width. Otherwise Malang-6 varieties that have stomata widest, has a density of stomata which includes the lower middle class. Because the two are mutually weakened the determinant variables resulted in stomatal conductivity did not differ between varieties and have no contact with one another

\section{Discussion}

Cassava varieties Ketan has higher total chlorophyll content and is different from the four other varieties but has a density of stomata stomata narrowest tenuous invitation, otherwise cassava varieties Singgah generate total chlorophyll content of at least but it has the most stomata and meetings. Malang- 6 cassava varieties produce enough chlorophyll content and density of stomata were in fact have the widest stomata. Leaf chlorophyll content directly affects the transmission and distribution of energy absorption of light and the photosynthetic efficiency is directly affected by photosynthetic leaf (Lin et al., 1992; Hou et al., 2013). The density of stomata of the leaves is negatively correlated with leaf chlorophyll. Conditions of water shortages and high light intensity during plant growth resulted in different responses to the varieties of cassava plant. Therefore the cassava plant will make modifications in the form of leaf anatomy stomata density becomes higher, due to surrounding cells that are smaller in size and leaves tend to be thicker (Morais et al., 2004; Pompelli et al., 2010). Tanspiration procces is influenced by a variety of internal factors such as the size of the leaves, the thickness of the leaves, the thickness of the wax layer, and the shape and location of the stomata and external such as; light radiation, temperature, humidity, light, wind and soil water content (Dardjat \& Arbayah, 1996; Suyitno \& Ratnawati, 2004). Selin was also influenced by the potential gradient between soil water, tissues and atmosphere, as well as the 
presence of toxic substances in the environment. Transpiration rate of has a positive relationship with the conductivity of stomata (Table 2). More details can be seen that the rate of transpiration has a higher correlation with stomatal density compared to the width of stomata. According to William et al. (2004), the rate of diffusion of water vapor through the stomata or transpiration is affected by the conductivity of stomata. Stomata conductivity in turn is influenced by the density and width of openings or stomata. According Goldworthy and Fisher (1992), the opening of the stomata is affected by $\mathrm{CO}_{2}$, light, humidity, temperature, wind, leaf water potential and photosynthesis rate. Rate of water loss control mechanisms control the rate of metabolism, structural adaptation of leaves reduces the rate of water loss, including arranging the conductivity of stomata. Although there is no real correlation between transpiration and $\mathrm{H}_{2} \mathrm{O}$ levels of cells, it is known that the higher the transpiration, the lower the levels of $\mathrm{H}_{2} \mathrm{O}$ cells. Burba and Pidwirny (2013) explain that transpiration is the actual transportation and is the evaporation of water from the plant body. The process of loss of water in the form of liquids, vapors or gases from plant tissues is mostly through stomata (Lovelles, 1991). The more rate of water loss, the more water content remaining in the plant body. Increased water levels affect cell turgor cover, length and width porusnya increase over changes in light intensity and cell cover curved outwards consequently formed cracks and porous open so the stomata open. Stomata conductivity plays a role in the speed control mechanism of transpiration and water loss on the process control network. Transpiration controls body fluids, absorption and transport of water, minerals and tissue temperature. Transpiration occurs through stomata, cuticle and lenticels. Stomata negatively correlated to $\mathrm{CO}_{2}$ content, but positively correlated and very significant effect on the rate of photosynthesis. $\mathrm{CO}_{2}$ and $\mathrm{O} 2$ gas exchange that occurs in the leaves is strongly influenced by the open and closing of stomata. Therefore, the conductivity of stomata influence the pace and outcome photosynthesis, as shown in Table 2. The rate of the cassava plant photosynthesis is affected by the width of stomata and $\mathrm{CO}_{2}$ concentration. Photosynthesis depends on a constant flow of $\mathrm{CO}_{2}$ and the ins and outs of cell $\mathrm{O}_{2}, \mathrm{CO}_{2}$ and $\mathrm{O}_{2}$ concentrations of cells and stomatal opening (Messinger et al., 2006). The low water potential causes stomatal closure and reduce leaf conductivity, impeding photosynthesis and transpiration and usually tie leaf temperature increases (Attridge, 1990). The content of $\mathrm{H}_{2} \mathrm{O}$ positively correlated to the rate of photosynthesis. The process of photosynthesis resulted in $\mathrm{CO}_{2}$ levels in the cell decreased. According to Chaves et al. (2003) and Nazar et al. (2015), that the decrease in stomatal $\mathrm{CO}_{2}$ concentration in the diffusion limitation effect on photosynthesis. The reaction of photosynthesis requires $\mathrm{CO}_{2}$, so that the high $\mathrm{CO}_{2}$ on plants and cassava enabling the rising rate of photosynthesis. $\mathrm{CO}_{2}$ in cassava varieties yangt Singgah low may result in a slow rate of photosynthesis, although only slightly faster than the local varieties Ketan. This was confirmed by Chavez et al. (2003) and Nazar et al. (2015), that the reduction in $\mathrm{CO}_{2}$ concentration limits the diffusion process and affects photosynthesis. Differences in the rate of photosynthesis between varieties strengthen the research Mahon et al. and Tan that the photosynthesis rate ranges from 15-45 $\mathrm{mg} \mathrm{CO}_{2} \mathrm{dn}^{-2}$ hour $^{-1}$. The rate of photosynthesis is different, in addition to the effect of genotype characteristics of cassava species is also due to the influence of correlation and the contribution of various physiological and other characters. Stomatal conductivity is the ability to be able to pass gas $\mathrm{CO}_{2}, \mathrm{O}_{2}, \mathrm{H}_{2} \mathrm{O}$ and other gases. High and low values of stomatal conductivity can be a limiting factor for the photosynthesis process associated with $\mathrm{CO}_{2}$ absorption that occurs in the leaves at noon (Da Matta et al., 2007). Theoretically conductivity should be affected joint stomata density and width of stomata, but the data of this study showed no such relationship. This occurs because the varieties Singgah and Adira-4 that have a high density of stomata, stomata tend to have a medium width. Instead varieties Malang-6 which has the widest stomata, has a density of stomata which includes the lower middle class. Because the two are mutually weakened the determinant variables resulted in stomatal conductivity did not differ between varieties and have no contact with one another

\section{References}

Adedeji, O., \& Jewoola, O. A. (2008). Importance of leaf epidermal characters in the Asteraceae Family, Notulae Botanicae. Horti Agrobotanici Cluj-Napoca, 36(2), 7-16.

Aien, I. A., Khetarpal, S., \& Pal, M. (2011). Photosynthetics of Potato cultivars grown under high temperature. American-Eurasian J. Agric. \& Environ. Sci., 11(5), 633-639.

Aspiazu, I., Sediyama, T., Rebiero Jr., J. I., Silva, A. A., Concenco, G., Ferreira, E. A., ... Araujo, W. F. (2006). Photosynthetic activity of cassava plants under weed campetition. Encyclopedia Britannica. Inc.

Attridge, T. H. (1990). The natural light environment. In T. H. Attridge (Ed.), Light and plant response (pp. 1-5). London: Edward Arnold.

Bahar, B. (2015). Relationships among flag leaf chlorophyll content, agronomical traits, and some physiological traits of winter wheat genotypes. Dicle University Institute of Natural and Applied Science Journal, 4(1), $1-5$. 
Borrell, A. K., Hammer, G. L., Henzell, R. G., \& Douglas, A. C. (2000). Genetic variation in transpiration efficiency of stay green and senescent sorghum hybrida grown under post anthesis drought. Crop Science.

Chaves, M. M., Maroco, J. P., \& Pereira, J. S. (2003). Understanding plant responses to drought from genes to the whole plant. Funct. Plant Biol., 30, 239-264. http://dx.doi.org/10.1071/FP02076

Christman, J. H., Richards, J. K., McKay, E. A. S., \& Juenger, T. A. (2008). Genetic variation in Arabidopsis thaliana for night-time leaf conductance. Plant Cell Environ., 31, 1170-1178. http://dx.doi.org/10.1111/j.1365-3040.2008.01833.x

Cowan, I. R. (1982). Water-use and optimization of carbon assimilation. In O. L. Lange, P. S. Nobel, C. B. Osmond, \& H. Ziegler (Eds.), Encyclopedia of plant physiology (New series, Vol. 12B). Model of water flow through plants incorporating shoot/root (pp. 589-613). Berlin, Heidelberg, New York: Springer-Verlag.

Crease, S. O., Rundel, P., \& Lawren, S. (2014). Are fern stomatal responses to different stimuli coordinated? Testing responses to light, vapor pressure deficit, and $\mathrm{CO}_{2}$ for diverse species grown under contrasting irradiances. New Phytologist, 204, 92-104. http://dx.doi.org/10.1111/nph.12922

DeMatta, F. M., Ronchi, C. P., Maestri, M., \& Barros, R. S. (2007). Ecophysiology of Coffea Growth and Production. Braz. J. Plant Physiol, 19(4), 485-510. http://dx.doi.org/10.1590/S1677-04202007000400014

Demmig, B.-A., \& Adams, W. W. (1990). The role of xanthophyll cycle carotenoids in the protection of photosynthesis. Trends in Plant Science, 1, 21-27. http://dx.doi.org/10.1016/S1360-1385(96)80019-7

El-Sharkawy, E., Sara, M. D. T., \& Luis, F. C. (2015). Potential Photosynthesis of Cassava as Affected by Growth Conditions. Contribution of the cassava physiology section. Cassava program Centro internacional de Agricultura Tropical (CIAT). A.A. 6713. Cali Colombia.

FAO. (2011). FAO's initiative on soaring food prices Guide for policy and programmatic actions at country level to address high food prices.

Franks, P. J., \& Farquhar, G. D. (2007). The Mechanical Diversity of Stomata and Its Significance in Gas-Exchange Control. Plant Physiol., 143, 78-87. http://dx.doi.org/10.1104/pp.106.089367

Gardner, F. P., Pearce, R. B., \& Mithhell, R. L. (1991). Fisiologi tumbuhan budidaya, terjemahan Herawati Susilo (pp. 247-275). Universitas Indonesia Press.

Gomez, K. A., \& Gomez, A. A. (1984). Statistical Procedures for Agricultural Research (2nd ed.). A Wiley Interscience Publication.

Hau, X., Li, R., Jia, Z., \& Han, Q. (2013). Rotational tillage improve photosynthesis of winter wheat during reproductive growth stages in a semiarid region. Agronomy Journal, 105, 215-221. http://dx.doi.org/ 10.2134/agronj2012.0201

Jones, H. G. (1998). Stomatal control of photosynthesis and transpiration. Journal of Experimental Botany, 49(Special Issue), 387-398. http://dx.doi.org/10.1093/jxb/49.Special_Issue.387

Lake, J. A., Quick, W. P., Beerling, D. J., \& Woodward, E. I. (2001). Signals from mature to new leaves nature (pp. 143-154).

Lin, S. Q., Xu, C. H., \& Zang, Q, D. (1992). Some aplication of chlorophyll fluorescence kineticks to plant physiology, ecology and agricultural modernization. Chin. Bull. Bot., 9, 1-16. http://dx.doi.org/CKNI:SUN: ZWXT.0.1992-01-000

Messinger, S. M. (2006). Evidence for involvement of photosynthetic processes in the stomatal response to $\mathrm{CO}_{2}$. Plant Physiol., 140(2), 771-7708. http://dx.doi.org/10.1104/pp.105.073676

Morais, H., Medri, M. E., Marur, C. J., Caraamori, P. H., Reberio dan, A. M. D. A., \& Gomes, J. C. (2004). Modification on leaf anatomy of cooofea arabica caused by shade of Pigeompea (Cajanus cajan). Brazillian Archives of Biology and Technology, 47(6), 863-871. http://dx.doi.org/10.1590/S1516-89132004000600005

Naves-Barbiero, C. C. (2000). Fluxo de selva e condutancia estomatica de duas especies lenhosas sempre-verdes no campo sujo e cerradao. R. Bras. Fisiol. Veg., 12(2), 119-134. http://dx.doi.org/10.1590/S0103-3131200 0000200003

Nazar, R., Umar, S., Khan, N. N., \& Sareer, O. (2015). Salicylic acid supplementation improves photosynthesis and growth in mustrad through changes in proline accumulation and ethylene formation under drought stress. South African Journal of Botany, 98(2015), 84-94. http://dx.doi.org/10.1016/j.sajb.2015.02.005 
Nuwamanya, E., Patrick, R. R., Denis, M., David, O., Yona, B., \& Joseph, F. H. (2015). The utility of biomarkers in selection for hydrothermal stress tolerance in cassava (Manihot esculenta Crantz). International Journal of Agriculture and Crop Sciences, 8(2), 235-248.

Nuwamanya, E., Patrick, R. R., Saetumba, M., Samuel, K., Joseph, H., \& Yona, B. H. (2014). Influence of spectral properties on cassava leaf development and metabolism. African Journal of Biotechnology, 13(7), 834-843. http://dx.doi.org/10.5897/AJB2013.12795

Okogbenin, E., Setter, T. L., Ferguson, M., Mutegi, R., Alves, A. C., Ceballos, H., \& Fregene, M. (2010). Phenotyping cassava for adaptation to drought. In P. Monneveux, \& J.-M. Ribaut (Eds.), Drought Phenotyping in Crops: From Theory to Practice (pp. 381-400). CIMMYT/Generation Challenge Programme, Mexico City.

Oliveira, E. C., \& Miglioranza, E. (2014). Stomatal Density in Six Genotypes of Cassava. International Journal of Engineering Science and Innovative Technology, 3(3).

Pompelli, M. F., Martins, S. C. V., Celin, E. F., Venterlla, M. C., \& DaMatta, F. M. (2010). Influence of ordinary epidermal cells and stomata on the leaf plasticity of plant grown under full-sun and shady condition. Braz. $J$. Biol., 70(4), 1083-1088. http://dx.doi.org/10.1590/S1519-69842010000500025

Ross, C. W. (1974). Plant Physiology Laboratory Manual (p. 200). Wardsworth, California.

Samonte, S. O., Wilson, P. B., \& Clung, A. M. Mc. (1998). Path analysis of yield and yiel and yield-related traits of fitten diverse rice genotype. Crop Sci., 38, 1130-1136. http://dx.doi.org/10.2135/cropsci1998.0011183X $003800050004 x$

Samuoliene, G., Brazaityte, J., Urbonavicuite, A., Sebajeviene, G., \& Duchoviskis, P. (2010). The effect of the blue and red light component on the growth and development of frugal berries.

SAS. (2002). Statistical Analysis System for Windows 9.0. SAS Institute Inc. SAS Campus Drive. Cary. North Carolina. USA.

Savvides, A., Fanourakis, D., \& Van Ieperen, W. (2012). Co-ordination of hydraulic and stomatal conductances across light qualities in cucumber leaves. J. Exp. Bot., 63, 1135-1143. http://dx.doi.org/10.1093/jxb/err348

Sinclair, T. R. R., \& Torrie, T. (1989). Leaf nitrogen, photosynthesis and crop radiation use efficiency. Crop Sci., 29, 90-98. http://dx.doi.org/10.2135/cropsci1989.0011183X002900010023x

Turyagyenda, L., Kizito, E. B., Ferguson, M., Baguma, Y., Agaba, M., \& Harvey, J. (2013). Physiological and molecular characterization of drought responses and identification of candidate tolerance genes in cassava. AoB PLANTS, 5. http://dx.doi.org/10.1093/aobpla/plt007

\section{Copyrights}

Copyright for this article is retained by the author(s), with first publication rights granted to the journal.

This is an open-access article distributed under the terms and conditions of the Creative Commons Attribution license (http://creativecommons.org/licenses/by/4.0/). 